\title{
Significance of CD30 Expression by Epidermotropic T Cells in Lymphomatoid Papulosis and Lymphomatoid Pityriasis Lichenoides
}

\author{
Eric C Vonderheid ${ }^{1 *}$, Marshall E Kadin², Gladys H Telang ${ }^{3}$ \\ ${ }^{1}$ Adjunct Professor, Sidney Kimmel Cancer Center, Johns Hopkins Medical Institutions, Baltimore, USA \\ ${ }^{2}$ Professor, Department of Dermatology, Boston University and Roger Williams Medical Center, Providence, RI, USA \\ ${ }^{3}$ Associate Professor, Department of Dermatology, The Warren Alpert Medical School of Brown University, RI, USA
}

Received: November 28, 2016; Accepted: January 27, 2017; Published: February 16, 2017

*Corresponding author: Eric Vonderheid, MD, 37580 S. Desert Sun Drive, Tucson, AZ 85739, USA, Tel: +520-825-2699; E-mail: evonder1@jhmi.edu

\section{Abstract}

Background: The $\mathrm{T}$ cell activation antigen $\mathrm{CD} 30$ is widely used to differentiate lymphomatoid papulosis (LyP) from pityriasis lichenoides. However, CD30 has recently been reported to be expressed by CD8+ cells in the epidermis and dermis of some cases of pityiasis lichenoides et varioliformis acuta (PLEVA).

Methods: This observation prompted us to review our experience with cases initially diagnosed as LyP or "lymphomatoid" pityriasis lichenoides for CD30 expression by epidermotropic T cells.

Results: CD30 expression by more than $20 \%$ of the epidermotropic $\mathrm{T}$ cells was observed in a group of 10 cases characterized clinically by self-healing papulonodules (two cases also with infiltrated plaques) and pathologically by atypical lymphocytes with cerebriform nuclei within the epidermis and dermal infiltrate.

Conclusions: CD30 can be expressed by either CD4+ or CD8+ cells in cases of LyP with epidermotropic T cells (so-called mixed LyP type A/B), but three of our cases appear to be examples of lymphomatoid CD30+ PLEVA. In addition, three cases had serologic manifestations suggestive of a lupus erythematosus-like autoimmune disorder. We hypothesize that CD30+ lymphocytes with cerebriform nuclei in some cases result in accumulation of benign activated CD8+ and CD4+ T cells rather than neoplastic cells.

Keywords: LYP (lymphomatoid papulosis); CD30; PLEVA (pityriasis lichenoides et varioliformis acuta); Lupus Erythematosus

\section{Introduction}

CD30, a lymphocyte activation antigen that is expressed by neoplastic $\mathrm{T}$ cells in a subset of mycosis fungoides and primary cutaneous CD30+ lymphoproliferative diseases, is widely used to differentiate lymphomatoid papulosis (LyP) from pityriasis lichenoides. [1, 2] Recently, Kempf and coworkers reported 13 unusual cases of the acute ulceronecrotic form of pityriasis lichenoides, i.e., pityriasis lichenoides et varioliformis acuta (PLEVA) or Mucha-Habermann disease, in which a large proportion of lymphocytes within the epidermis and dermis expressed CD30. [3] As is frequently observed in PLEVA lesions, a large proportion of lymphocytes in the dermal infiltrate and overlying epidermis of their cases expressed CD8 (median, 70\%; range 50 to $90 \%$ ). However unlike typical PLEVA, CD30 was co-expressed by these cells (median, 60\%; range, 15 to $80 \%$ ). Other $\mathrm{T}$ cell markers including CD7 were present. Of note, CD3 was expressed by less than $50 \%$ of dermal lymphocytes in 3 of 7 specimens, often seen in mycosis fungoides. [4] Notably, molecular or serologic evidence of parvovirus B19 infection was found in a majority of their patients.

Kempf's paper prompted us to review our experience with patients initially diagnosed to have LyP or "lymphomatoid" pityriasis lichenoides for CD30 expression by epidermotropic $\mathrm{T}$ cells. We discovered that CD30 expression by more than $20 \%$ of the epidermotropic $\mathrm{T}$ cells identifies a heterogeneous group characterized clinically by self-healing papules and occasionally small nodules (two cases also with infiltrated plaques) and pathologically by atypical lymphocytes with convoluted or cerebriform nuclei (cerebriform lymphocytes) within the epidermis and dermal infiltrate. Three of our 10 patients may have CD30+ PLEVA although one patient (described below) also had specimens that were typical of LyP, an observation that supports the concept of a close pathogenic relationship exists between these conditions. $[3,5,6]$ We also discovered a possible association of CD30+ cutaneous lymphoproliferative disorders with undeclared lupus erythematosus.

\section{Methods}

All cases were evaluated by one of us (ECV) for recurrent, often crusted and/or purpuric self-healing papules or occasionally small nodules (two cases also with infiltrated plaques) and prior histopathologic evidence of atypical lymphocytes in the dermal infiltrate, suggesting a diagnosis of LyP or lymphomatoid pityriasis lichenoides. Skin biopsy specimens were bisected with one-half of the specimen processed for routine histology and one-half frozen for immunohistochemical studies that included antibodies reactive against CD2, CD3, CD4, CD5, CD7, CD8, CD62L 
and CD30. Only cases in which CD30 was expressed by more than $20 \%$ of the epidermotropic T cells were selected (Table 1). The percentage of positively labeled cells in the dermal infiltrate was visually estimated. LyP specimens with epidermotropic cerebriform lymphocytes and also atypical immunoblast-like cells with vesiculated nuclei and prominent nucleoli, sometimes resembling Reed-Sternberg cells, in the dermal infiltrate were classified as a mixed type of LyP (LyP-A/B) or type C LyP (LyP-C) depending on the density of atypical cells in the dermal infiltrate. Six specimens were also studied for evidence of a dominant $\mathrm{T}$ cell clone by polymerase chain reaction (PCR) for rearrangement of the $\mathrm{T}$ cell receptor gamma chain $(\mathrm{TCR}-\gamma)$ chain gene.

\section{Results}

The clinical and pathologic findings of 10 cases $(1$ male, 9 females; ages 12 to 78 years) that fulfilled the selection criteria are summarized in Table 1. Because of self healing papulonodules with cerebriform lymphocytes in the epidermis, the differential diagnosis included LyP, lymphomatoid pityriasis lichenoides and "pityriasis lichenoides-like" mycosis fungoides.[7,8] The specimen of patient 1 , which was obtained from an infiltrated 2.3 $\mathrm{cm}$ plaque, is an example of borderline LyP-C/anaplastic large cell lymphoma (ALCL). Specimens from patients 2 and 3 are considered to be examples of CD4+ LyP-A/B. In 5 other cases, most epidermotropic T cells were CD8+. The specimens of patients 5, 6 and 7 also had a substantial number of admixed CD4+ cells within the epidermis. Because cerebriform lymphocytes were present in the epidermis and dermis, the findings were considered to be most consistent with LyP-A/B with a component of reactive CD8+ cells although CD8+ LyP or CD8+ pityriasis lichenoides-like mycosis fungoides were in the differential diagnosis.

Patient 6 illustrates that skin specimens obtained at different times can vary between pityriasis lichenoides and LyP. Prior to referral, two specimens showed characteristic features of pityriasis lichenoides with absent or rare CD30+ dermal cells and two other specimens showed features typical for LyP-A with many CD30+ cells in the dermis (Figures 1 and 2).

The papule from patient 7, who had co-existing patch phase mycosis fungoides, had typical histopathologic features of LyPA/B with $20 \%$ CD30+ cells within the epidermis, but without $\mathrm{CD} 30+$ cells in the dermal infiltrate despite the presence of

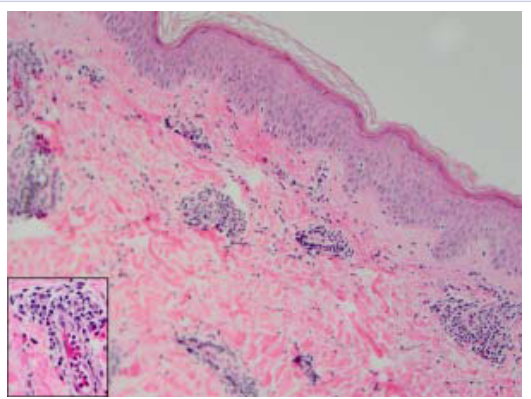

Figure 1: Skin specimen of papule from patient 6 shows a perivascular infiltrate in the upper dermis without involvement of the epidermis. Large atypical lymphocytes are present in the infiltrate and many neutrophils are within the vessel (Insert).

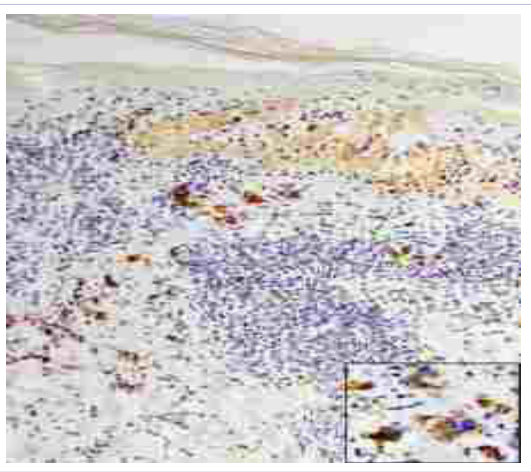

Figure 2: A stain for CD30 on the same specimen shown in Figure 1 confirmed the presence of scattered large CD30+ cells in the dermal infiltrate, but not within the epidermis. This section also shows a dense dermal infiltrate with a subepidermal vesicle.

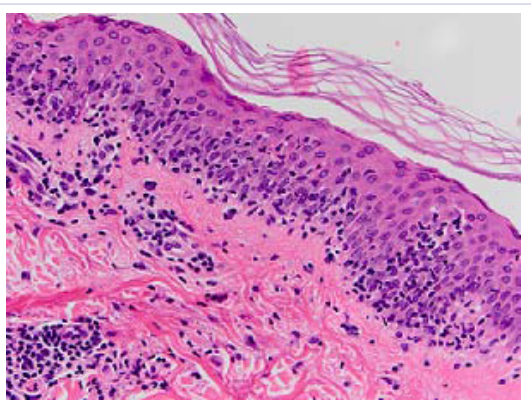

Figure 3: Biopsy from a papule of patient 6 shows numerous medium to large sized atypical lymphocytes, some with cerebriform nuclei, concentrated along the basal layer of the epidermis, scattered apoptotic keratinocytes, and a wedge-shaped dermal infiltrate composed of both normal and atypical lymphocytes.

atypical immunoblast-like cells. Of interest, immunophenotyping of a patch of mycosis fungoides done elsewhere also showed CD8+ epidermotropic T cells (CD30 staining not performed).

Patient 8, who had been diagnosed to have LyP-A (histopathology only), presented with self-healing papules with histologic features of LyP-C, specifically a wedge-shaped infiltrate containing numerous large atypical cells with prominent nucleoli including Reed-Sternberg-like cells, many eosinophils and mitotic figures, extravasated erythrocytes, and margination of neutrophils in blood vessels (Table 1, Figure 4). The immunophenotype of these atypical cells was CD8+CD4CD30+ indicating the possibility of aggressive primary cutaneous epidermotropic CD8+ cytotoxic T-cell lymphoma, also known as Berti's lymphoma. $[10,11]$ The infiltrate was not angiocentric nor was vasculitis present, features characteristic of LyP-E. [12] Epidermotropic T cells were CD8+ and approximately one-half expressed of CD30. Although the patient's disease responded well to low doses of methotrexate, her disease would abruptly recur when methotrexate doses were reduced. (Figure 5). Seven and one half years after initial presentation, the patient developed a $3 \mathrm{~cm}$ tumor on her palm. The biopsy specimen contained a dense nodular dermal infiltrate of morphologically similar cells as the initial specimen with $80 \%$ of cells expressing CD30. A diagnosis 


\begin{tabular}{|c|c|c|c|c|c|c|c|c|}
\hline Case & $\mathbf{A} / \mathbf{R} / \mathbf{G}$ & $\begin{array}{l}\text { Duration; Clinical } \\
\text { Examination; } \\
\text { Impression }\end{array}$ & $\begin{array}{l}\text { Epidermal } \\
\text { Changes }\end{array}$ & $\begin{array}{l}\text { Dermal } \\
\text { Changes }\end{array}$ & Lymphocytes & Immunohistochemistry & TCR- $\gamma$ & Final DX \\
\hline 1 & $52 \mathrm{WF}$ & $\begin{array}{l}4 \text { mo; Regressed Paps } \\
\text { plus } 2.3 \mathrm{~cm} \mathrm{PQ} \\
\text { LyP-C }\end{array}$ & Ep (many) & Li, PV, I, PA, M & $\begin{array}{l}\text { Medium-large } \\
\text { HC CLs and } \\
\text { LVC }\end{array}$ & $\begin{array}{l}\text { ED: } 100 \% \text { CD2+3+4+8-5-7-62L- } \\
\text { CD30+; } \\
\text { D: CD2 90\%, CD3 90\%, CD4 90\%, } \\
\text { CD5 10\%, CD7 10\%, CD8 1\%, } \\
\text { CD62L } 20-30 \%, \text { CD30 70-80\% }\end{array}$ & $\begin{array}{c}\text { Pos } \\
\text { (SSCP) }\end{array}$ & $\begin{array}{l}\text { LyP-C/ } \\
\text { ALCL }\end{array}$ \\
\hline 2 & $50 \mathrm{WF}$ & $\begin{array}{c}5 \text { mo; } \\
\text { Crusted 5-6 mm Paps; } \\
\text { LyP-A/B }\end{array}$ & U, Ep (many) & $\begin{array}{c}\text { Li, PV, Neu (v), } \\
\text { EE, M }\end{array}$ & $\begin{array}{l}\text { Medium-large } \\
\text { HC CLs plus } \\
\text { LVC/RSC in } \\
\text { dermis }\end{array}$ & $\begin{array}{c}\text { ED: } 100 \% \text { CD2+3+4+5+7+8-62L+, } \\
50 \% \text { CD30+; } \\
\text { D: CD2 90\%, CD3 90\%, CD4 > 95\%, } \\
\text { CD5 > 95\%, CD7 > 95\%, CD8< } \\
10 \%, \text { CD62L 90\%, CD30 20\% }\end{array}$ & ND & LyP-A/B \\
\hline 3 & $34 \mathrm{BF}$ & $\begin{array}{c}5 \text { yr; } \\
\text { Crusted 3-8 mm Paps; } \\
\text { LyP-A/B }\end{array}$ & U, A, Ep (many) & $\begin{array}{c}\text { PV, I, SC, PDE, } \\
\text { Eos, EE, Vas }\end{array}$ & $\begin{array}{l}\text { CLs plus LVC } \\
\text { in dermis }\end{array}$ & $\begin{array}{c}\text { ED: CD4 >> CD8, } \\
\text { > 50\% CD30+; } \\
\text { D: CD2 95\%, CD3 95\%, CD4 95\%, } \\
\text { CD5 40-50\%, CD7 20\%, CD8 10- } \\
\text { 20\%, CD62L 40-50\%, CD30 20- } \\
30 \%\end{array}$ & $\begin{array}{c}\text { Neg } \\
\text { (SSCP) }\end{array}$ & LyP-A/B \\
\hline 4 & $12 \mathrm{WF}$ & $\begin{array}{c}1 \text { yr; } \\
\text { Crusted \& scaly 3-5 mm } \\
\text { Paps; LyP-A/B vs L-PL }\end{array}$ & A, P, Ep (many) & Li, PV, PA, EE & $\begin{array}{l}\text { Small CLs plus } \\
\text { few medium } \\
\text { sized CLs in } \\
\text { dermis }\end{array}$ & $\begin{array}{l}\text { E: CD8 > CD4, scattered CD30+;* } \\
\text { D: CD2 90\%, CD3 90\%, CD4 70\%, } \\
\text { CD5 50\%, CD7 30\%, CD8 65\%, } \\
\text { CD62L 50\%, CD30 5-10\% }\end{array}$ & $\begin{array}{c}\text { Neg } \\
\text { (DGGE) }\end{array}$ & LyP-A/B \\
\hline 5 & $16 \mathrm{WF}$ & $\begin{array}{c}5 \text { mo; } \\
\text { Purpuric \& scaly 1-2 mm } \\
\text { Paps; } \\
\text { LyP-B vs L-PL }\end{array}$ & $\begin{array}{l}\text { A, P, U, Ep } \\
\text { (many) }\end{array}$ & $\begin{array}{l}\text { Li, PV, PDE, } \\
\text { EE, Eos, Vas, } \\
\text { PA }\end{array}$ & $\begin{array}{c}\text { Medium, } \\
\text { occasional } \\
\text { large HC CLs } \\
\text { also in dermis }\end{array}$ & $\begin{array}{c}\text { ED: CD8 > CD4, } \\
\text { > 70\% CD30+; } \\
\text { D: CD2 80\%, CD3 90\%, CD4 60\%, } \\
\text { CD5 40\%, CD7 20\%, CD8 40\%, } \\
\text { CD62L 50-60\%, CD30 40\% }\end{array}$ & $\begin{array}{l}\text { Neg } \\
\text { (SSCP) }\end{array}$ & LyP-A/B \\
\hline 6 & $35 \mathrm{WF}$ & $\begin{array}{c}15 \text { mo; } \\
\text { Crusted \& purpuric 1-3 } \\
\text { mm Paps; } \\
\text { LyP-B vs L-PL }\end{array}$ & U, Ep (many) & $\begin{array}{c}\mathrm{Li}, \mathrm{PV}, \mathrm{EE}, \mathrm{Neu} \\
\text { (v) }\end{array}$ & $\begin{array}{c}\text { Medium-large } \\
\text { CLs }\end{array}$ & $\begin{array}{c}\text { ED: CD8 > CD4, } \\
\text { 60\% CD30+; } \\
\text { D: CD2 90\%, CD3 90\%, CD4 90\%, } \\
\text { CD5 80\%, CD7 40\%, CD8 40\%, } \\
\text { CD62L 90\%, CD30 5\% }\end{array}$ & $\begin{array}{c}\text { Pos } \\
\text { (DGGE) }\end{array}$ & LyP-A/B \\
\hline 7 & $36 \mathrm{WM}$ & $\begin{array}{c}7 \text { yr; Ulcerated \& crusted } \\
\text { Paps + PTs } \leq 5 \mathrm{~cm} \neq \\
\text { MFPT + LyP-A/B }\end{array}$ & $\begin{array}{l}\mathrm{A}, \mathrm{U}, \mathrm{Ep}(\mathrm{B}, \\
\text { many) }\end{array}$ & $\begin{array}{c}\text { Li, PV, MF, Neu } \\
\text { (v), EE }\end{array}$ & $\begin{array}{l}\text { Medium-large } \\
\text { HC CLs plus } \\
\text { LVC in dermis }\end{array}$ & $\begin{array}{c}\text { E: CD8 >> CD4, 20\% CD30+; } \\
\text { D: CD2 70\%, CD3 80\%, CD4 60\%, } \\
\text { CD5 80\%, CD7 50\%, CD8 40\%, } \\
\text { CD62L 60\%, CD30 0\% }\end{array}$ & ND & LyP-A/B \\
\hline 8 & $78 \mathrm{WF}$ & $\begin{array}{c}12 \text { yr; } \\
\text { Crusted \& purpuric 3-5 } \\
\text { mm Paps; LyP-C }\end{array}$ & U, Ep (focal?) & $\begin{array}{l}\text { Li, PV, MF, Eos, } \\
\text { EE, Neu (v) }\end{array}$ & $\begin{array}{l}\text { Small CLs, } \\
\text { LVC/RSC }\end{array}$ & $\begin{array}{c}\text { ED: CD8 >> CD4, > 50\% CD30+; } \\
\text { D: > } 50 \% \text { CD2+3+4-5+/-7-8+30+ } \\
\text { cells }\end{array}$ & ND & LyP-C \\
\hline 9 & $77 \mathrm{WF}$ & $\begin{array}{c}2 \text { yr; } \\
\text { Purpuric 1-5 mm Paps; } \\
\text { LyP-B }\end{array}$ & $\begin{array}{l}\text { U, VA, Ep } \\
\text { (many) }\end{array}$ & PV, Neu (v), EE & $\begin{array}{c}\text { Medium-large } \\
\text { HC CLs }\end{array}$ & $\begin{array}{l}\text { ED: Weak CD4 \& CD8§, CD30+; } \\
\text { D: CD2 90\%, CD3 60\%, CD4 50\%, } \\
\text { CD5 40\%, CD7 40\%, CD8 50\%, } \\
\text { CD62L 50\%, CD30 0\% }\end{array}$ & ND & LyP-B§ \\
\hline 10 & $59 \mathrm{WF}$ & $\begin{array}{c}5 \text { yr; } \\
\text { 3-15 mm Pap/Nds \& } \\
\text { two arcuate } 3.5,8 \mathrm{~cm} \\
\text { PQs; L-PL vs LyP \& MF } \\
\text { vs SLE\# }\end{array}$ & $\begin{array}{c}\text { A, VA, NK, EE, Ep } \\
\text { (Many, basalar) }\end{array}$ & Li, W, EE, Eos & $\begin{array}{c}\text { Medium-large } \\
\text { HC CLs also } \\
\text { dermis }\end{array}$ & $\begin{array}{c}\text { ED: CD4 = CD8, many CD30+*; } \\
\text { D: CD2 90\%, CD3 90\%, CD4 90\%, } \\
\text { CD5 60\%, CD7 40\%, CD8 40\%, } \\
\text { CD62L 60\%, CD30<5\% }\end{array}$ & $\begin{array}{c}\text { Neg } \\
\text { (DGGE) }\end{array}$ & $\begin{array}{c}\text { See } \\
\text { discussion }\end{array}$ \\
\hline \multicolumn{9}{|c|}{ 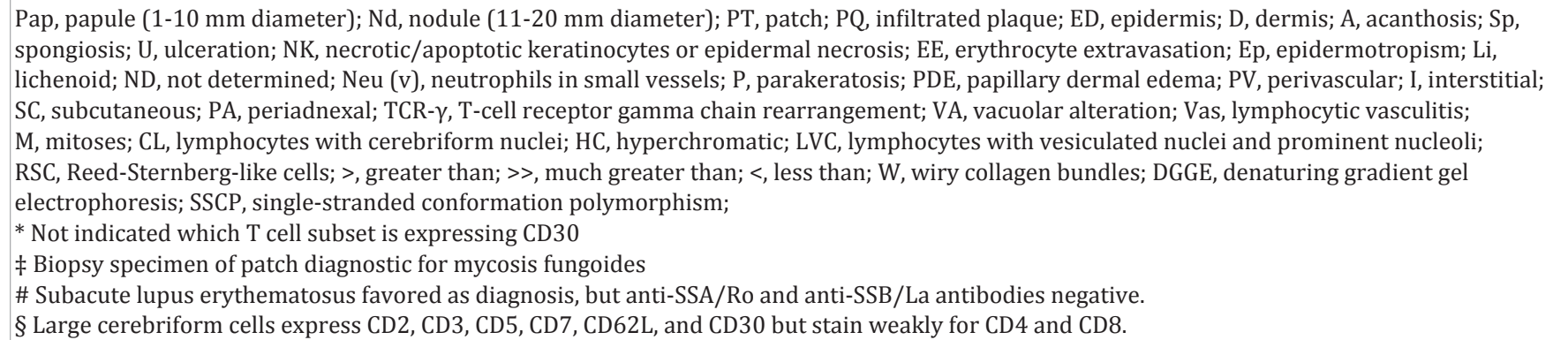 } \\
\hline
\end{tabular}


of secondary ALCL was rendered and local field radiotherapy was given with good response. The patient died 5 months later, but the specific cause of death is unknown.

A papule from patient 9 had no $\mathrm{CD} 30+$ cells in the dermal infiltrate and was diagnosed as LyP-B. The large intraepithelial $\mathrm{T}$ cells in this case expressed an unusual CD3+CD4dimCD8dimCD30+ immunophenotype. In addition these cells expressed CD2, variable CD5, CD7, and CD62L. The CD4 CD8 double positive phenotype has been observed in a few cases of LyP-A or LyP-C including one case with the 6p25.3 translocation $[9,14-15]$ and mycosis fungoides. [15] It is also possible that CD4+CD8+ neoplastic $\mathrm{T}$ cells differentiated from double negative precursor cells under influence of thymic-like hormones produced in vivo by keratinocytes. [16] However, CD1 was not expressed, a finding that argues against differentiation from immature thymocytes. Alternatively, stimulation of CD4+ neoplastic $\mathrm{T}$ cells in the epidermis might have induced expression of CD8. [17]

Finally, similar to patient 1 , patient 10 presented with scattered self-healing 3 to $15 \mathrm{~mm}$ papulonodules along with two infiltrated plaques on the face and antecubital fossa (Figures 6 and 7). A biopsy obtained from a papule 3 months before referral showed some vacuolar interface alteration and extravasated erythrocytes, but also lymphocytes with enlarged hyperchromatic and somewhat pleomorphic nuclei in the dermal infiltrate. (Figure 8) These atypical cells were CD30-negative and the tentative diagnosis was lymphomatoid pityriasis lichenoides.

This patient also had a prior history of urticarial vasculitis and photosensitivity, suggesting that the facial plaques were a manifestation of subacute lupus erythematosus although this could not be confirmed by serologic studies. The specimen taken from a small plaque on the thigh showed a band-like dermal infiltrate, vacuolar interface alterations with apoptotic keratinocytes, but also many small-medium sized cerebriform lymphocytes in the epidermis and superficial dermis that supported a diagnosis of mycosis fungoides (Figures 9 and 10). The epidermotropic cells consisted of a mixture of CD4+ and CD8+ cells, many of which expressed CD30 and scattered CD30+

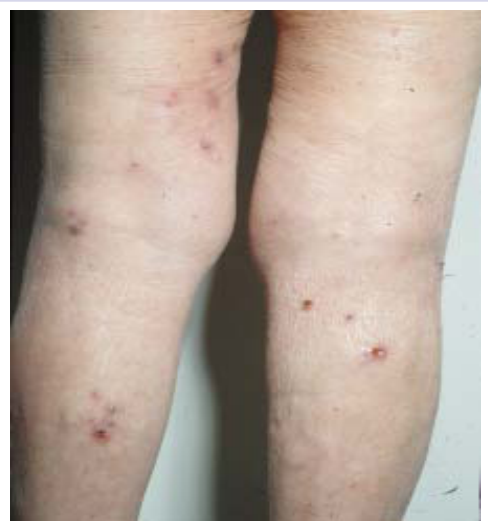

Figure 4: Patient 8 presented in July 1989 with a 12 year history of scattered 2 to $5 \mathrm{~mm}$ ulceronecrotic papules that would regress spontaneously on the trunk and extremities.

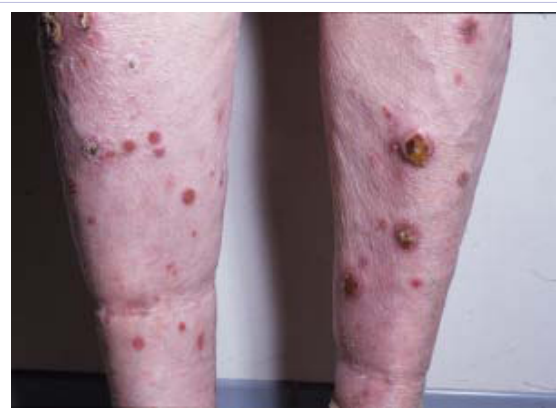

Figure 5: Three years after presentation, patient 8 developed numerous papules and crusted nodules that suddenly appeared when methotrexate was withdrawn.

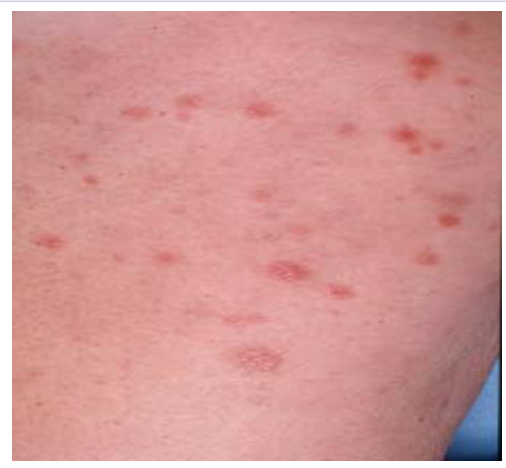

Figure 6: Patient 10 presented with erythematous 3 to $15 \mathrm{~mm}$ papulonodules and small plaques in different stages of evolution on her thighs and elsewhere.

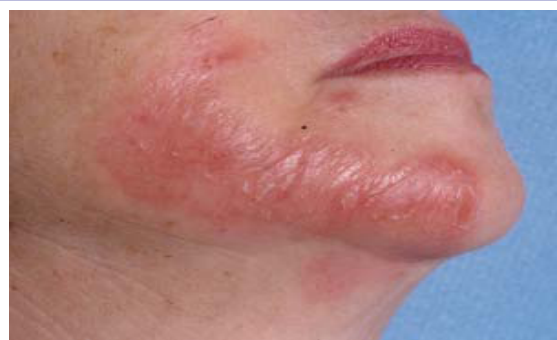

Figure 7: Patient 10 also had 3 by $8 \mathrm{~cm}$ erythematous plaque on the right mandibular area.

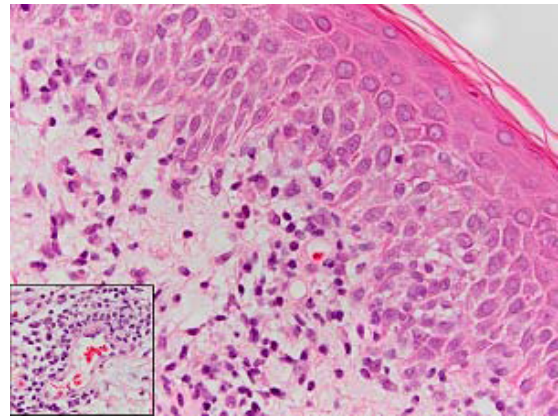

Figure 8: Specimen obtained from a papule of patient 10 shows an interface dermatitis with vacuolar alteration of the basal layer of the epidermis, and lymphocytes with large hyperchromatic nuclei in the dermal infiltrate (Insert). 


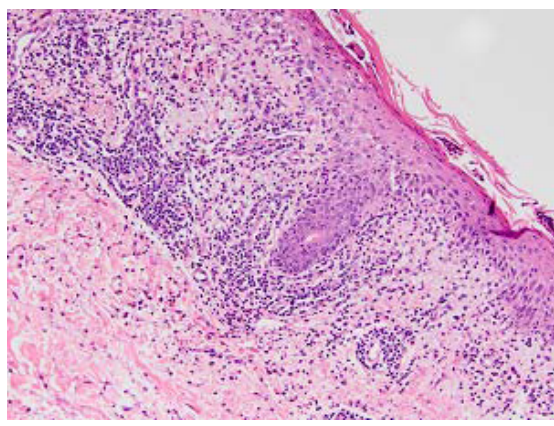

Figure 9: Specimen from a small plaque on the thigh of patient 10 (shown in figure 6) reveals a band-like lymphoid infiltrate in the upper dermis and involvement of the overlying epidermis.

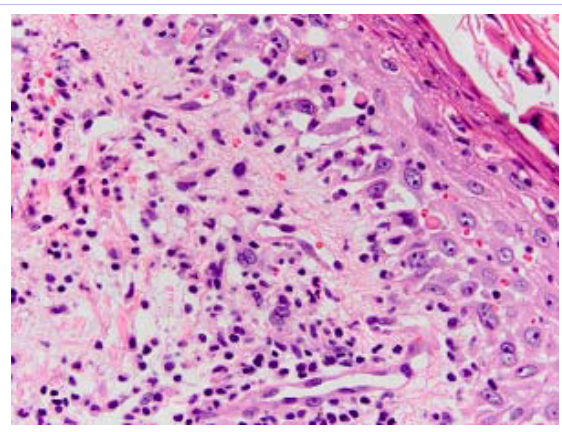

Figure 10: The epidermis shows apoptotic keratinocytes and atypical medium to large sized lymphocytes with hyperchromatic nuclei. Eosinophils and extravasated erythrocytes are also present.

cells were in the dermal infiltrate. Although mycosis fungoides occurring in a patient with pre-existing lymphomatoid pityriasis lichenoides (or LyP-B) seemed possible, in retrospect, this patient may have had plaques of subacute lupus erythematosus with epidermotropic cerebriform lymphocytes that mimic mycosis fungoides as described by Magro.[18] Unfortunately no follow up information is available to clarify the diagnosis.

In addition to patient 10, two other patients in this series (cases 2 and 6) had manifestations suspicious for a concomitant connective tissue disorder. Specifically, patient 2 had fatigue, arthralgias, positive antinuclear antibody (1:1280 titer, homogeneous pattern), elevated sedimentation rate, biologic false positive RPR, and thrombocytopenia, but no antibodies against double-stranded DNA, cardiolipin, SSA/Ro, SSB/La, and extractable nuclear antigens. Patient 6 also had fatigue, arthralgias, positive antinuclear antibody (1:640 titer, nucleolar and fine speckled pattern) and single-stranded DNA antibody tests, but negative double-stranded DNA antibody and other autoimmune serologies including anti-SSA/Ro and SSB/La antibodies.

\section{Discussion}

We herein report that a high proportion of CD30+ epidermotropic $\mathrm{T}$ cells with cerebriform nuclei may be encountered in skin lesions of patients with CD4+ and CD8+ LyP. CD30+ epidermotropic T cells may also occur in PLEVA and mycosis fungoides. $[3,19]$ It is conceivable that three of the LyPA/B cases (patients 4 to 6 ) are examples of lymphomatoid CD30+ PLEVA, especially patient 6 whose lesions showed features of both entities over time. Given that CD30 is an lymphocyte activation antigen and that normal $\mathrm{T}$ cells when stimulated in vitro via CD3 or CD2 in the presence of phorbol esters can develop cerebriform nuclei, [20] we hypothesize that CD30+ cerebriform lymphocytes in some cases might be the result of accumulation of benign stimulated CD8+ and CD4+ T cells rather than neoplastic cells. Finally, it is noteworthy that 3 of our patients had clinical and serologic manifestations suggestive of a lupus erythematosuslike autoimmune disorder. This observation may be more than fortuitous considering that chronic virus infections including parvovirus B19 are suspected to trigger pityriasis lichenoides, LyP, and lupus erythematosus. [3, 21-24]

We conclude that CD30 may be rarely expressed not only by CD8+ cells in some cases of PLEVA as reported by Kempf, [3] but also by epidermotropic $\mathrm{T}$ cells in lesions with histopathologic features of LyP. Our observation that one of our patients had both types of lesions suggests the possibility of a related histogenesis between LyP and CD30+ PLEVA, We demonstrate the variability of CD30 positivity in this heterogeneous population of selfhealing papulonodules. Furthermore, some patients with CD30+ epidermotropic $\mathrm{T}$ cells had manifestations of a lupus-like autoimmune disorder, the significance of which warrants further investigation.

\section{Acknowledgement}

Dr. Kadin receives support from the Drs. Martin and Dorothy Spatz Charitable Foundation.

\section{References}

1. Varga FJ, Vonderheid EC, OlbrichtSM, Kadin ME. Immunohistochemical distinction of lymphomatoid papulosis and pityriasis lichenoides et varioliformis acuta. Am J Pathol. 1990;136(4):979-987.

2. Erpaiboon P, Mihara I, Niimura M. Lymphomatoid papulosis: clinicopathological comparative study with pityriasis lichenoides et varioliformis acuta. J Dermatol. 1991;18(10):580-585.

3. Kempf W, Kazakov DV, Palmedo G, Fraitag S, Schaerer L, Kutzner H. Pityriasis lichenoides et varioliformis acuta with numerous CD30(+) cells: a variant mimicking lymphomatoid papulosis and other cutaneous lymphomas. A clinicopathologic, immunohistochemical, and molecular biological study of 13 cases. Am J Surg Pathol. 2012;36(7):1021-1029. doi: 10.1097/PAS.0b013e31824f4f66.

4. Pimpinelli N, Olsen EA, Santucci M, Vonderheid E, Haeffner AC, Stevens $S$, et al. Defining early mycosis fungoides. J Am Acad Dermatol. 2005;53(6):1053-1063.

5. Abel EA, Deneau DG, Warnke RA. Immunohistology of pityriasis lichenoides et varioliformis acuta and pityriasis lichenoides chronica. Evidence for their interrelationship with lymphomatoid papulosis. J Am Acad Dermatol. 1987;16(3 Pt 1):559-570.

6. Vonderheid EC, Kadin ME, Gocke CD. Lymphomatoid papulosis followed by pityriasis lichenoides: a common pathogenesis? Am J Dermatopathol. 2011;33(8):835-840. doi: 10.1097/ DAD.0b013e3181f4d8c3.

7. Ko JW, Seong JY, Suh KS, Kim ST. Pityriasis lichenoides-like mycosis fungoides in children. Br J Dermatol. 2000;142(2):347-352. 
8. Cho EB, Youn SH, Park EJ, Kwon IH, Kim KH, Kim KJ. CD8-positive pityriasis lichenoides-like mycosis fungoides. Eur J Dermatol. 2012;22(3):415-416. doi: 10.1684/ejd.2012.1701.

9. El Shabrawi-Caelen L, Kerl H, Cerroni L. Lymphomatoid papulosis: reappraisal of clinicopathologic presentation and classification into subtypes A, B, and C. Arch Dermatol. 2004;140(4):441-447.

10. Robson A, Assaf C, Bagot M, Burg G, Calonje E, Castillo C, et al Aggressive epidermotropic cutaneous $\mathrm{CD}^{+}$lymphoma: a cutaneous lymphoma with distinct clinical and pathological features. Report of an EORTC Cutaneous Lymphoma Task Force Workshop. Histopathology, 2015;67(4):425-441. doi: 10.1111/his.12371.

11. Tsujiwaki M, Abe R, Ohguchi Y, Hoshina D, Murata J, Fujita Y, et al Recurrent course and CD30 expression of atypical T lymphocytes distinguish lymphomatoid papulosis from primary cutaneous aggressive epidermotropic CD8+ cytotoxic T-cell lymphoma. Acta Derm Venereol. 2014;94(5):613-614. doi: 10.2340/00015555-1806.

12. Kempf W, Kazakov DV, Schärer L,Rütten A, Mentzel T, Paredes BE, et al. Angioinvasive lymphomatoid papulosis: a new variant simulating aggressive lymphomas. Am J Surg Pathol. 2013;37(1):1-13. doi: 10.1097/PAS.0b013e3182648596.

13. Wood GS, Strickler JG, Deneau DG, Egbert B, Warnke RA Lymphomatoid papulosis expresses immunophenotypes associated with $\mathrm{T}$ cell lymphoma but not inflammation. J Am Acad Dermatol. 1986;15(3):444-458.

14. Karai LJ, Kadin ME, Hsi ED, Sluzevich JC, Ketterling RP, Knudson RA, et al. Chromosomal rearrangements of 6 p25.3 define a new subtype of lymphomatoid papulosis. Am J Surg Pathol. 2013;37(8):1173-1181. doi: 10.1097/PAS.0b013e318282d01e.

15. Parekh V, Shim EH, Knapp CF 3rd, Hughey L, Elmets CA, McKay K Primary cutaneous T-cell lymphoma with coexpression of T-cell receptors $\alpha \beta$ and $\gamma \delta$. Am J Dermatopathol. 2016;38(1):66-72. doi 10.1097/DAD.0000000000000355.

16. Safai B, Incefy GS, Good RA, Dardenne M. T-cell differentiating activity in tissue cultures containing mycosis fungoides epidermal cells. N Engl J Med. 1980;303(2):113.
17. Overgaard NH, Jung JW, Steptoe RJ, Wells JW. CD4+/CD8+ doublepositive T cells: more than just a developmental stage? J Leukoc Biol. 2015;97(1):31-38. doi: 10.1189/jlb.1RU0814-382.

18. Magro CM, Crowson AN, Harrist TJ. Atypical lymphoid infiltrates arising in cutaneous lesions of connective tissue disease. Am J Dermatopathol. 1997;19(5):446-455

19. Wu H, Telang GH, Lessin SR, Vonderheid EC. Mycosis fungoides with CD30-positive cells in the epidermis. Am J Dermatopathol. 2000;22(3):212-216.

20. Reinhold U, Herpertz M, Kukel S, Oltermann I, Uerlich M, Kreysel HW. Induction of nuclear contour irregularity during $\mathrm{T}$-cell activation via the T-cell receptor/CD3 complex and CD2 antigens in the presence of phorbol esters. Blood. 1994;83(3):703-706.

21. Tomasini D, Tomasini CF, Cerri A, Sangalli G, Palmedo G, Hantschke M, et al. Pityriasis lichenoides: a cytotoxic T-cell-mediated skin disorder. Evidence of human parvovirus B19 DNA in nine cases. J Cutan Pathol. 2004;31(8):531-538.

22. Wenzel J, Gütgemann I, Distelmaier M, Uerlich M, Mikus S, Bieber T, et al. The role of cytotoxic skin-homing CD8+ lymphocytes in cutaneous cytotoxic T-cell lymphoma and pityriasis lichenoides. J Am Acad Dermatol. 2005;53(3):422-427.

23. Kim JE, Yun WJ, Mun SK, Yoon GS, Huh J, Choi JH, et al. Pityriasis lichenoides et varioliformis acuta and pityriasis lichenoides chronica: comparison of lesional T-cell subsets and investigation of viral associations. J Cutan Pathol. 2011;38(8):649-56. doi: 10.1111/j.16000560.2011.01717.

24. Nelson P, Rylance P, Roden D, Trela M, Tugnet N. Viruses as potential pathogenic agents in systemic lupus erythematosus. Lupus. 2014;23(6):596-605. doi: 10.1177/0961203314531637. 